\title{
Autosomal dominant axonal Charcot-Marie-Tooth disease type 2 (CMT2G) maps to chromosome 12q12-q13.3
}

\author{
E Nelis, J Berciano, N Verpoorten, K Coen, I Dierick, V Van Gerwen, O Combarros, P De Jonghe, \\ V Timmerman
}

J Med Genet 2004;41:193-197. doi: 10.1136/jmg.2003.012633

C harcot-Marie-Tooth (CMT) disease is a clinically and genetically heterogeneous group of disorders that involve the peripheral nervous system. ${ }^{1}$ It is characterised by progressive distal neurogenic muscular atrophy and weakness that initially affects the peroneal muscles and later the hands. Charcot-Marie-Tooth disease type 1 (CMT1), also called hereditary motor and sensory neuropathy type I (HMSN I), is a dominantly inherited demyelinating neuropathy characterised by reduced nerve conduction velocities (NCV) (motor median NCV $<38 \mathrm{~m} / \mathrm{s}$ ). Charcot-Marie-Tooth disease type 2 (CMT) 2, or HMSN II, is a dominantly inherited axonal neuropathy characterised by normal or slightly reduced NCV. Both autosomal dominant CMTI and autosomal dominant CMT2 are genetically heterogeneous, with five and six loci, respectively. ${ }^{2}$ Most patients with CMTl have a $1.4 \mathrm{Mb}$ tandem duplication on chromosome 17pll.2 (CMTIA (MIM 118220)). ${ }^{3}$ Other patients with CMT1 may have point mutations in the peripheral myelin protein 22 gene (PMP22 in CMT1A (MIM 60197)), ${ }^{5}$ myelin protein zero gene (MPZ in CMT1B (MIM 159440)), ${ }^{6}$ lipopolysaccharide induced tumour necrosis factor gene (LITAF in CMTIC (MIM 603795)), ${ }^{7}$ early growth response 2 gene (EGR2 in CMTID (MIM 129010)), ${ }^{8}$ or the gap junction protein beta 1 gene (GJB1 in CMT1X (MIM 304040)). . Patients with CMT2 may have point mutations in the kinesin family member $1 \mathrm{~B}$ gene (KIFIB in CMT2A (MIM 605995)), ${ }^{10}$ RAB7, member RAS oncogene family (RAB7 in CMT2B (MIM 602298)), ${ }^{11}$ glycyl tRNA synthetase (GARS in CMT2D (MIM 600287)), ${ }^{12}$ or neurofilament light polypeptide (NEFL in CMT2E (MIM 607684)). ${ }^{13}$ The genes for CMT2C and CMT2F have not been identified yet. ${ }^{14}$ 15 Some patients with CMT2 have also been reported to have specific mutations in the MPZ gene. ${ }^{16}{ }^{17}$

\section{METHODS}

We previously described a large Spanish family diagnosed with autosomal dominant CMT2. ${ }^{18}$ For this study, we enlarged the pedigree to 28 people, of whom 14 were diagnosed as affected (fig 1). The age at onset was 9-76 (mean 29) years. Most patients developed symptoms in the second decade of life. The disease, which presented with foot deformity and difficulty walking, showed a very slow progression. Patients were mildly disabled. Ankle reflexes were absent or hypoactive in all patients, whereas knee reflexes sometimes were preserved. Mild stocking hypaesthesia was seen. The upper limbs were involved in only two patients. Scoliosis, pupillary abnormalities, foot ulcers, deafness, diaphragm and vocal cord paralysis, nerve enlargement, optic atrophy, tremor, and ataxia were absent.

Electrophysiological findings were updated for this study. Briefly, we found slight slowing of motor NCV (77-93\% of lower limit of normal) in $30 \%$ of nerves tested. Interestingly, five patients had entirely normal NCV values. Distal compound motor action potentials and sensory nerve action potentials in the lower limbs had low amplitudes or were

\section{Key points}

- Charcot-Marie-Tooth (CMT) neuropathies are heterogeneous clinically and genetically. For the autosomal dominant axonal type of CMT or CMT type 2 (CMT2), six loci and four genes have been reported.

- A genomewide scan was performed in a Spanish family with autosomal dominant CMT2 not linked to the known CMT2 loci and conclusive linkage with a chromosome 12q13.13 marker was obtained. Fine mapping localised this novel CMT2 locus to a 13.2 Mb (12.8 cM) interval between DI2S1663 and D12S1644 at 12q12-q13.3.

- The candidate genes advillin (AVIL), centaurin gamma 1 (CENTG1), a member of the RAS oncogene family $(R A B 5 B)$, and the desert hedgehog homologue (Drosophila) $(\mathrm{DHH})$ were excluded.

- As the CMT2 neuropathy in this family represents a novel genetic entity, it was designated CMT2G.

unobtainable. Electromyography of tibialis anterior muscles showed chronic neurogenic alterations. The histological study of two sural nerve biopsies and a sciatic nerve and its branches that we dissected in an amputated leg of patient 117.3 showed loss of myelinated fibres with a proximal to distal gradient, clusters of regenerating fibres, and atrophic axons. ${ }^{18}$ Autopsy of patient 117.102 showed loss of anterior horn and dorsal root ganglion neurons in the lumbosacral segments and degeneration of the fasciculus gracilis. Morphometric evaluation of the L5 ventral and dorsal roots showed a normal number of myelinated fibres, while diameter histograms were shifted to the left because of a significant loss of large myelinated fibres and regeneration. ${ }^{18}$

DNA from 28 individuals, of whom 11 were affected, was available for genetic analysis. Informed consent was obtained according to the Declaration of Helsinki, and protocols were approved by the Institutional Review Board of the Marqués de Valdecilla University Hospital. We previously had excluded the CMTIA tandem duplication at 17pl1.2 and mutations in PMP22, MPZ, and NEFL (data not shown). Furthermore, we performed genetic linkage studies and excluded known CMT2 loci with short tandem repeat markers from these regions (data not shown). We performed a genomewide scan with 382 short tandem repeat markers of the ABI Prism Linkage Mapping Set (version 2.5; Applied Biosystems, Foster City, CA, USA), which had an average intermarker distance of $10 \mathrm{cM}$. Markers were amplified by polymerase chain reaction (PCR) on a PTC-220 DNA Engine DYAD (MJ Research, Waltham, MA, USA) and pooled with a Biomek FX 
Laboratory Workstation (Beckman Coulter, Fullerton, CA, USA). We performed and processed fragment analysis by capillary electrophoresis on an ABI Prism 3700 DNA Analyzer (Applied Biosystems, Foster City, CA, USA) and with GeneScan Analysis software (version 3.5; Applied Biosystems, Foster City, CA, USA) and Genotyper software (version 3.7; Applied Biosystems, Foster City, CA, USA). We performed genetic fine mapping with additional short tandem repeat markers selected from the ABI Prism Linkage Mapping Set HD-5 (Applied Biosystems, Foster City, CA, USA) (D12S1682, D12S1640, and D12S1663) or UCSC Human Genome Browser (April 2003 Freeze) and the genome database (D12S1687, Di2S1713, D12S1632, D12S1644, and D12S90).

We computed two point linkage between the disease gene and each marker with Linkage software (version 5.1) and Fastlink software (version 2.1, freely available). ${ }^{19}{ }^{20}$ We scored CMT2 as a $90 \%$ penetrant autosomal dominant trait with a gene frequency of 0.0001 . We assumed equal recombination rates between men and women. For each short tandem repeat marker, we set the number of alleles in the logarithm of odds (LOD) score calculations at the observed number of alleles in the pedigree $(\mathrm{N})$ and the allele frequencies at $\mathrm{l} / \mathrm{N}$.

We designed primers for PCR amplification of the coding region of the candidate genes with Primer3 $(R A B 5 B)$ or our in house software SNPbox (AVIL, CENTG1) (S. Weckx et al, personal communication, 2003) (table 2, supplementary data) or used published primers $(D H H) .{ }^{21}$ We sequenced the PCR products, which were prepared for sequencing with the PCR Product Pre-Sequencing Kit (USB Corporation, Cleveland, OH, USA), with the BigDye Terminator Cycle Sequencing kit and AmpliTaq DNA polymerase FS (Applied Biosystems, Foster City, CA, USA). We removed unincorporated dye terminators with MultiScreen 96-well filtration plates (Millipore, Bedford, MA, USA). We performed electrophoresis on an ABI Prism 3730 DNA analyser (Applied Biosystems, Foster City, CA, USA). We collected sequencing data with the ABI DNA Sequencing Analysis software (version 3.6) and analysed them with the SeqMan II software (version 5.06 DNASTAR, Madison, WA, USA).

\section{RESULTS}

In the initial genomewide search, significant linkage to marker D12S368 (LOD score $\mathrm{z}=4.10$ at $\theta=0$ ) and suggestive linkage to the neighbouring marker D12S85 (LOD score $\mathrm{z}=2.92$ at $\theta=0$ ) were obtained on chromosome 12q13.1 (table 1). We performed genetic fine mapping with additional short tandem repeat markers. Table 1 summarises the two point LOD scores. Segregation analysis in the family identified the disease haplotype in all patients (163, 171, $122,210,275$, and 213) with markers D12S1687, D12S1713, D12S85, D12S368, D12S1604, and D12S1632 (fig 1). Two key meiotic recombinants were identified between D12S1663 and D12S1687 in patient 117.9 and between D12S1632 and D12S1644 in patient 117.16. These two recombinants assigned the CMT2 gene to a $13.2 \mathrm{Mb}$ region (UCSC Human Genome Browser, April 2003 Freeze) between centromeric D12S1663 and telomeric D12S1644 at 12q12q13.3. Simultaneous with the fine mapping, we screened four candidate genes in the linked region: advillin (AVIL), centaurin gamma 1 (CENTG1), RAB5B member RAS oncogene family $(R A B 5 B)$, and desert hedgehog homologue (Drosophila) gene $(\mathrm{DHH})$. Sequence analysis of the complete coding regions of the genes showed a nucleotide change in intron 13 (c.1550-49C >T) of CENTG1. Segregation analysis of this non-coding single nucleotide polymorphism in the family indicated that the single nucleotide polymorphism was transmitted with the CMT2 phenotype, except in one patient (117.16). This recombination event was confirmed by marker D12S1644 in the same patient (figs 1 and 2). The CENTG1 single nucleotide polymorphism is not related, therefore, to the disease in this family affected by CMT2. In addition, analysis of 154 control chromosomes did not identify the c.1550-49C $>$ T single nucleotide polymorphism, which suggests that this single nucleotide polymorphism is rare.

\section{DISCUSSION}

We report a novel genetic locus of a $12.8 \mathrm{cM}$ linkage region at 12 q12-q13.3 in a Spanish autosomal dominant family with CMT2. It is the seventh locus for autosomal dominant CMT2, so we designated it CMT2G. The CMT2 region is covered by one sequenced contig (NT_029419) and contains more than 300 genes (UCSC Human Genome Browser, April 2003 Freeze). We screened the coding region of four candidate genes in the linked region. AVIL and CENTGI were considered functional candidates, as they are expressed in the peripheral nervous system (Verpoorten et al., unpublished data, 2003). RAB5B was considered a good candidate, as it is highly homologous to RAB7-the gene in which mutations cause $C M T 2 B .{ }^{11} D H H$ may be involved in perineurial development in peripheral nerves. ${ }^{22}$ No disease causing mutations were detected, which excluded these four genes as the CMT2 genes.

Table 1 Two point LOD scores between the CMT2 locus and short tandem repeat markers on chromosome 12q12-q13.3

\begin{tabular}{|c|c|c|c|c|c|c|c|c|}
\hline \multirow[b]{2}{*}{ Marker } & \multicolumn{8}{|c|}{ LOD score at recombination fraction $(\theta)$} \\
\hline & 0.00 & 0.001 & 0.01 & 0.05 & 0.10 & 0.20 & 0.30 & 0.40 \\
\hline D12S364 & -6.38 & -2.82 & -0.83 & 0.55 & 1.05 & 1.24 & 1.00 & 0.51 \\
\hline D12S310 & 1.16 & 1.16 & 1.15 & 1.08 & 0.98 & 0.79 & 0.56 & 0.30 \\
\hline D12S1682 & -3.54 & -1.28 & -0.28 & 0.43 & 0.68 & 0.79 & 0.67 & 0.40 \\
\hline D12S1617 & -5.09 & -1.52 & 0.43 & 1.65 & 1.98 & 1.92 & 1.44 & 0.72 \\
\hline D12S1640 & 0.84 & 0.84 & 0.85 & 0.87 & 0.86 & 0.74 & 0.55 & 0.30 \\
\hline D12S345 & -3.53 & -0.49 & 0.47 & 0.99 & 1.05 & 0.86 & 0.52 & 0.17 \\
\hline D12S1663 & -0.70 & 1.30 & 2.24 & 2.66 & 2.61 & 2.15 & 1.49 & 0.71 \\
\hline D12S1687 & 2.64 & 2.64 & 2.62 & 2.51 & 2.32 & 1.84 & 1.25 & 0.56 \\
\hline D12S1713 & 2.64 & 2.64 & 2.62 & 2.51 & 2.32 & 1.84 & 1.25 & 0.56 \\
\hline D12S85 & 2.92 & 2.92 & 2.90 & 2.77 & 2.56 & 2.04 & 1.39 & 0.63 \\
\hline D12S368 & 4.10 & 4.10 & 4.06 & 3.86 & 3.55 & 2.82 & 1.94 & 0.93 \\
\hline D12S1604 & 4.08 & 4.08 & 4.04 & 3.84 & 3.54 & 2.81 & 1.94 & 0.93 \\
\hline D12S1632 & 4.56 & 4.55 & 4.49 & 4.18 & 3.78 & 2.93 & 1.98 & 0.94 \\
\hline D12S1644 & -3.95 & -0.95 & 0.05 & 0.71 & 0.91 & 0.93 & 0.74 & 0.42 \\
\hline D12S90 & -3.02 & -0.04 & 0.94 & 1.52 & 1.62 & 1.43 & 1.00 & 0.46 \\
\hline D12S83 & -0.70 & 1.30 & 2.24 & 2.66 & 2.61 & 2.15 & 1.49 & 0.71 \\
\hline
\end{tabular}




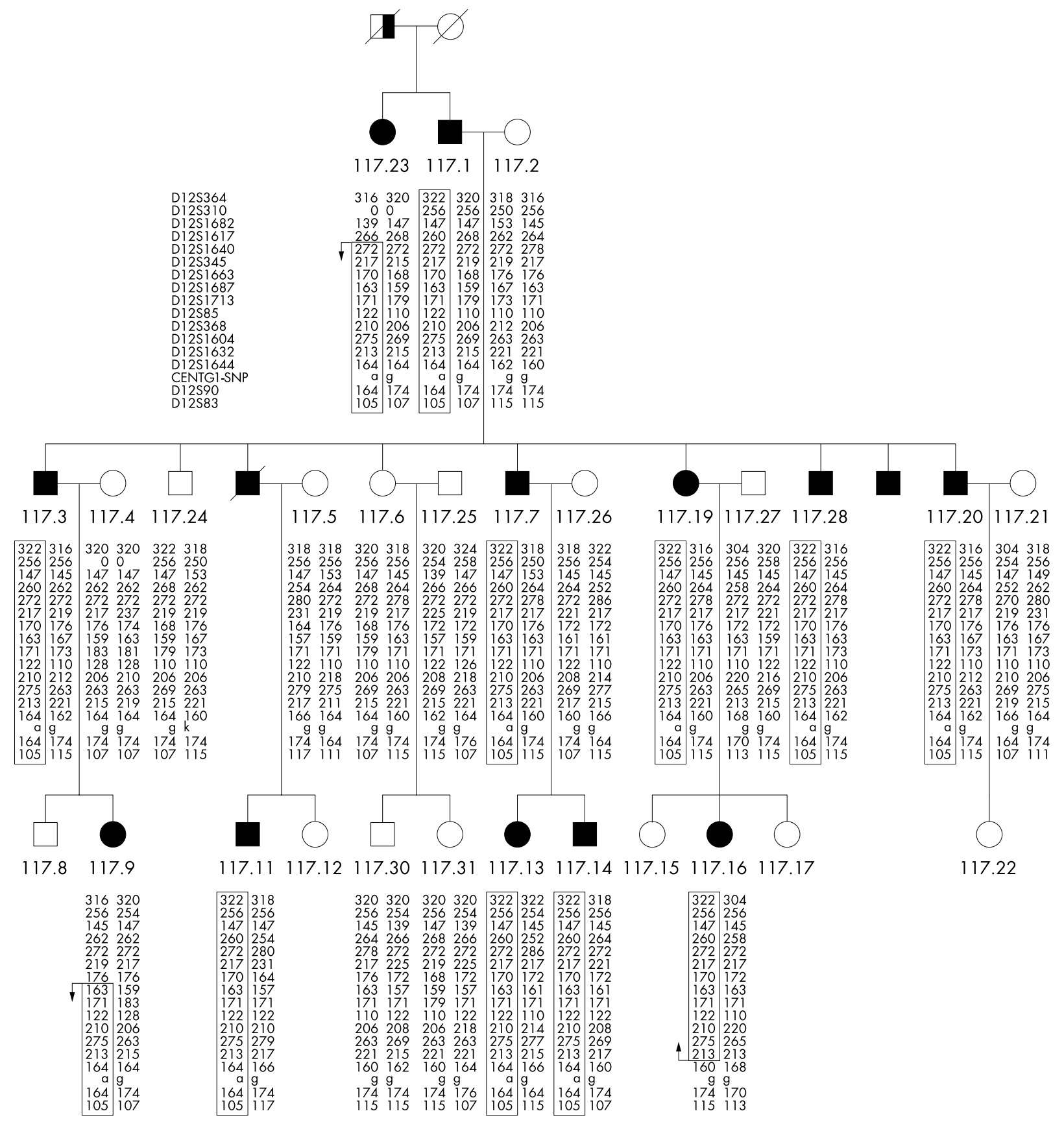

Figure 1 Haplotype analysis in the pedigree of the Spanish autosomal dominant family with CMT2 CMT-117. For confidentiality reasons, we did not reveal the genotypes of the asymptomatic people who were at risk in the youngest generation. Alleles were sized according to the Centre $d^{\prime}$ Etude du Polymorphisme Humain (CEPH) control DNA (1347.02) and are shown in base pairs. Short tandem repeat markers are shown from centromere (top) to telomere (bottom). The haplotype associated with the disease is boxed. Patient 117.9 defines the centromeric border of the disease at D12S1663, while patient 117.16 defines the telomeric border at D12S1644. affected woman; affected man; $\bigcirc$ unaffected woman; $\square$ unaffected man; a man of unknown status; / deceased; 0 failed genotype.

Chromosome 12q contains several loci for neuromuscular disorders: CMT2C at 12q23-q24, ${ }^{14}$ dominant congenital distal spinal muscular atrophy at $12 \mathrm{q} 23-\mathrm{q} 24,{ }^{23}$ distal hereditary motor neuropathy type II (distal HMN II) at $12 \mathrm{q} 24,{ }^{24}$ spinocerebellar ataxia type 2 (SCA2; gene SCA2) at 12q24, ${ }^{25}$ scapuloperoneal spinal muscular atrophy (SPSMA) at 12q24.1-q34.31, ${ }^{26}$ scapuloperoneal muscular dystrophy (SPMD) at 12q15-q23.1, ${ }^{27}$ gonadal dysgenesis with minifascicular neuropathy (gene $D H H$ ) at $12 q_{13.1,}{ }^{21}$ spastic paraplegia type 10 (SPG10; gene KIF5A) at $12 \mathrm{q} 13.3,{ }^{28}$ centronuclear myopathy (gene MYF6) at $12 \mathrm{q} 21,{ }^{29}$ and restless leg syndrome at $12 \mathrm{q} 12-\mathrm{q} 21 .^{30}$ Only the gonadal dysgenesis with minifascicular neuropathy region overlaps with the $C M T 2 G$ region. The gene associated with this disorder, $D H H$, was excluded by mutation analysis.

The electrophysiological and pathological findings in the Spanish pedigree affected by CMT showed that the neuropathy primarily is axonal and therefore can be classified as CMT2. ${ }^{31} 32$ The clinical phenotype is characterised by a classic, although mild, peroneal muscular atrophy syndrome. Additional features were absent, which indicates that this neuropathy presents as a pure variant of CMT. 


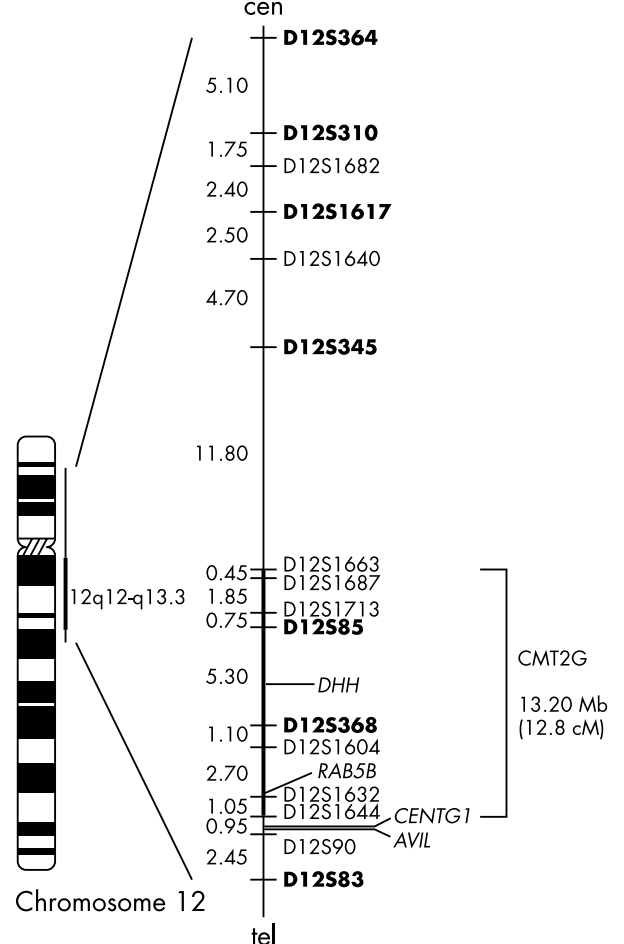

Figure 2 Genetic map of chromosome 12q12-q13 region. Physical distances between the markers $(\mathrm{Mb})$ were obtained from the UCSC Human Genome Browser (April 2003 Freeze). A bold line indicates the CMT2G region. Markers in bold are from the ABI Prism Linkage Mapping Set (version 2.5)

\section{Conclusion}

We report a novel genetic locus of a $12.8 \mathrm{cM}$ linkage region at 12q12-q13.3 in a Spanish autosomal dominant CMT2 family. Clinical and genetic analysis of additional CMT2 families will help to fine map the locus and identify the genetic defect that causes CMT2G.

\section{ACKNOWLEDGEMENTS}

The authors gratefully acknowledge the cooperation and participation of all family members in this study and the contribution of the VIB Genetic Service Facility (http://www.vibgeneticservicefacility.be/) in the genetic analyses. This research project was supported by Fund for Scientific Research-Flanders (Belgium) (FWO-Vlaanderen), Special Research Fund of the University of Antwerp, Medical Foundation Queen Elisabeth, Association Belge contre les Maladies Neuro-Musculaires, Interuniversity Attraction Poles programme P5/ 19 of the Belgian Federal Science Policy Office, Muscular Dystrophy Association (USA), and Centro de Investigación de Enfermedades Neurológicas (ISCIII, Madrid, Spain). EN is a postdoctoral fellow and $\mathrm{KC}$ is a research assistant of the FWO-Vlaanderen. NV and ID are supported by a fellowship from the Institute for Science and technology (IWT), Belgium.

\section{Authors' affiliations}

E Nelis, N Verpoorten, K Coen, I Dierick, V Van Gerwen,

V Timmerman, P De Jonghe, Molecular Genetics Department, Flanders Interuniversity Institute for Biotechnology, University of Antwerp,

Antwerp, Belgium

J Berciano, O Combarros, Division of Neurology, Marqués de Valdecilla University Hospital, University of Cantabria, Santander, Spain P De Jonghe, Division of Neurology, University Hospital Antwerp (UZA), Antwerp, Belgium

Correspondence to: Dr E Nelis, Department of Molecular Genetics (VIB8), Peripheral Neuropathy Group, University of Antwerp (UIA

\section{Electronic database information}

- Inherited peripheral neuropathies mutation database (IPNMDB) (http://molgen-www.uia.ac.be/ CMTMutations/)

- Genome database (http://www.gdb.org/)

- Online Mendelian inheritance in man (OMIM) (http:// www.ncbi.nlm.nih.gov/omim)

- Primer3 (http://www-genome.wi.mit.edu/cgi-bin/ primer/primer3_www.cgi)

- UCSC Human Genome Browser (http://genome. ucsc.edu/goldenPath/septTracks.html)

- Fastlink (http://www.ncbi.nlm.nih.gov/CBBresearch/ schaffer/fastlink.html)

Campus Drie Eiken), Universiteitsplein 1, B-2610 Antwerp, Belgium; eva.nelis@ua.ac.be

Received: 21 July 2003

Accepted: 5 September 2003

Conflict of interest: None declared.

\section{REFERENCES}

1 Dyck PJ, Chance P, Lebo R, Carney JA. Hereditary motor and sensory neuropathies. In: Dyck PJ, Thomas PK, Griffin JW, Low PA, Poduslo JF, eds. Peripheral neuropathy. Philadelphia: WB Saunders, 1993:1094-136.

2 Kuhlenbäumer G, Young P, Hunermund G, Ringelstein B, Stogbauer F. Clinical features and molecular genetics of hereditary peripheral neuropathies. J Neurol 2002;249:1629-50

3 Raeymaekers $\mathrm{P}$, Timmerman V, Nelis E, De Jonghe P, Hoogendijk JE, Baas F, Barker DF, Martin J-J, de Visser M, Bolhuis PA, Van Broeckhoven C. HMSN Collaborative Research Group. Duplication in chromosome 17p11.2 in Charcot-Marie-Tooth neuropathy type la (CMT la). Neuromusc Disord $1991 ; 1: 93-7$.

4 Lupski JR, Montes de Oca-Luna R, Slaugenhaupt S, Pentao L, Guzzetta V, Trask BJ, Saucedo-Cardenas O, Barker DF, Killian JM, Garcia CA, Chakravarti A, Patel PI. DNA duplication associated with Charcot-MarieTooth disease type 1A. Cell 1991;66:219-39.

5 Valentijn LJ, Baas F, Wolterman RA, Hoogendijk JE, van den Bosch NHA, Zorn I, Gabreëls-Festen AAWM, de Visser M, Bolhuis PA. Identical point mutations of PMP-22 in Trembler-J mouse and Charcot-Marie-Tooth disease type 1A. Nature Genet 1992;2:288-91.

6 Hayasaka K, Himoro M, Sato W, Takada G, Uyemura K, Shimizu N, Bird T, Conneally PM, Chance PF. Charcot-Marie-Tooth neuropathy type 1B is associated with mutations of the myelin P0 gene. Nature Genet 1993;5:31-4.

7 Street VA, Bennett CL, Goldy JD, Shirk AJ, Kleopa KA, Tempel BL, Lipe HP, Scherer SS, Bird TD, Chance PF. Mutation of a putative protein degradation gene LITAF/SIMPLE in Charcot-Marie-Tooth disease 1C. Neurology 2003:60:22-6.

8 Warner LE, Mancias P, Butler IJ, McDonald CM, Keppen L, Koob G, Lupski JR. Mutations in the early growth response 2 (EGR2) gene are associated with hereditary myelinopathies. Nature Genet 1998;18:382-4.

9 Bergoffen J, Scherer SS, Wang S, Oronzi Scott M, Bone U, Paul DL, Chen K, Lensch MW, Chance PF, Fischbeck KH. Connexin mutations in X-linked Charcot-Marie-Tooth disease. Science 1993;262:2039-42.

10 Zhao C, Takita J, Tanaka Y, Setou M, Nakagawa T, Takeda S, Wei Yang H, Terada S, Nakata T, Takei Y, Saito M, Tsuji S, Hayashi Y, Hirokawa N. Charcot-Marie-Tooth disease type 2A caused by mutation in a microtubule motor KIF1B. Cell 2001;105:587-97.

11 Verhoeven K, De Jonghe P, Coen K, Verpoorten N, Auer-Grumbach M, Kwon JM, FitzPatrick D, Smedding E, De Vriendt E, Jacobs A, Van Gerwen V, Wagner K, Hartung HP, Timmerman V. Mutations in the small GTP-ase late endosomal protein RAB7 cause Charcot-Marie-Tooth type 2B neuropathy. Am J Hum Genet 2003;72:722-7.

12 Antonellis A, Ellsworth RE, Sambuughin N, Puls I, Abel A, Lee-Lin SQ, Jordanova A, Kremensky I, Christodoulou K, Middleton LT, Sivakumar K, lonasescu V, Funalot B, Vance JM, Goldfarb LG, Fischbeck KH, Green E, eds. Glycyl tRNA synthetase mutations in Charcot-Marie-Tooth disease type 2D and distal spinal muscular atrophy type V. Am J Hum Genet 2003;72:1293-9.

13 Mersiyanova IV, Perepelov AV, Polyakov AV, Sitnikov VF, Dadali EL, Oparin RB, Petrin A, Evgrafov OV. A new variant of Charcot-Marie-Tooth disease type 2 (CMT2E) is probably the result of a mutation in the neurofilament light gene. Am J Hum Genet 2000;67:37-46.

14 Klein CJ, Cunningham JM, Atkinson EJ, Schaid DJ, Hebbring SJ, Anderson SA Klein DM, Dyck PJ, Litchy WJ, Thibodeau SN, Dyck PJ. The gene for HMSN2C maps to 12q23-24: a region of neuromuscular disorders. Neurology 2003:60:1151-6. 
15 Ismailov SM, Fedotov VP, Dadali EL, Polyakov AV Van Broeckhoven C, Ivanov VI, De Jonghe P, Timmerman V, Evgrafov OV. A new locus for autosomal dominant Charcot-Marie-Tooth disease type 2 (CMT2F) maps to chromosome 7q11-q21. Eur J Hum Genet 2001;9:646-50.

16 De Jonghe $\mathbf{P}$, Timmerman V, Ceuterick C, Nelis E, De Vriendt E, Löfgren A Vercruyssen A, Verellen C, Van Maldergem L, Martin J-J, Van Broeckhoven C. The Thr124Met mutation in the peripheral myelin protein zero (MPZ) gene is associated with a clinically distinct Charcot-Marie-Tooth phenotype. Brain 1999;122:281-90.

17 Marrosu GM, Vaccargiu S, Marrosu G, Vannelli A, Cianchetti C, Muntoni F. Charcot-Marie-Tooth disease type 2 associated with mutation of the myelin protein zero gene. Neurology 1998;50:1397-401

18 Berciano J, Combarros O, Figols J, Calleja J, Cabello A, Silos I, Coria F. Hereditary motor and sensory neuropathy type II. Clinicopathological study of a family. Brain 1986;109:897-914.

19 Lathrop GM, Lalovel J-M. Easy calculations of lod scores and genetic risk on small computers. Am J Hum Genet 1984;36:460-5.

20 Cottingham RW, Idury RM, Schäffer AA. Faster sequential genetic linkage computations. Am J Hum Genet 1993:53:252-63.

21 Umehara F, Tate G, Itoh K, Yamaguchi N, Douchi T, Mitsuya T, Osame M. A novel mutation of desert hedgehog in a patient with $46, X Y$ partial gonadal dysgenesis accompanied by minifascicular neuropathy. Am J Hum Genet 2000:67:1302-5

22 Parmantier E, Lynn B, Lawson D, Turmaine M, Namini SS, Chakrabarti L, McMahon AP, Jessen KR, Mirsky R. Schwann cell-derived desert hedgehog controls the development of peripheral nerve sheaths. Neuron 1999:23:713-24.

23 van der Vleuten AJW, van Ravenswaaij-Arts CMA, Friins CJM, Smits APT, Hageman G, Padberg GW, Kremer H. Localisation of the gene for a dominant congenital spinal muscular atrophy predominantly affecting the lower limbs to chromosome 12q23-q24. Eur J Hum Genet 1998;6:376-82.

24 Timmerman V, De Jonghe P, Simokovic S, Löfgren A, Beuten J, Nelis E, Ceuterick C, Martin J-J, Van Broeckhoven C. Distal hereditary motor neuropathy type II (distal HMN II): Mapping of a locus to chromosome 12q24. Hum Mol Genet 1996;5:1065-9.

25 Pulst SM, Nechiporuk A, Nechiporuk T, Gispert S, Chen XN, Lopes-Cendes I, Pearlman S, Starkman S, Orozco-Diaz G, Lunkes A, DeJong P, Rouleau GA Auburger G, Korenberg JR, Figueroa C, Sahba S. Moderate expansion of a normally biallelic trinucleotide repeat in spinocerebellar ataxia type 2. Nat Genet 1996;14:269-76.

26 Isozumi K, Delong R, Kaplan J, Deng HX, lqbal Z, Hung WY, Wilhelmsen KC, Hentati A, Pericak-Vance MA, Siddique T. Linkage of scapuloperoneal spinal muscular atrophy to chromosome 12q24.1-q24.31. Hum Mol Genet 1996:5:1377-82

27 Wilhelmsen KC, Blake DM, Lynch T, Mabutas J, De Vera $M$, Neystat $M$, Bernstein M, Hirano M, Gilliam TC, Murphy PL, Sola MD, Bonilla E, Schotland DL, Hays AP, Rowland LP. Chromosome 12-linked autosomal dominant scapuloperoneal muscular dystrophy. Ann Neurol 1996;39:507-20

28 Reid E, Kloos M, Ashley-Koch A, Hughes L, Bevan S, Svenson IK, Graham FL, Gaskell PC, Dearlove A, Pericak-Vance MA, Rubinsztein DC, Marchuk DA. A kinesin heavy chain (KIF5A) mutation in hereditary spastic paraplegia (SPG10). Am J Hum Genet 2002;71:1189-94.

29 Kerst B, Mennerich D, Schuelke M, Stoltenburg-Didinger G, von Moers A, Gossrau R, van Landeghem FK, Speer A, Braun T, Hubner C. Heterozygous myogenic factor 6 mutation associated with myopathy and severe course of Becker muscular dystrophy. Neuromuscul Disord 2000;10:572-7.

30 Desautels A, Turecki G, Montplaisir J, Sequeira A, Verner A, Rouleau GA. Identification of a major susceptibility locus for restless legs syndrome on chromosome 12q. Am J Hum Genet 2001;69:1266-70.

31 Dyck PJ, Lambert EH. Lower motor and primary sensory neuron diseases with peroneal muscular atrophy. II. Neurologic, genetic, and electrophysiologic findings in various neuronal degenerations. Arch Neurol 1968; 18:619-25.

32 Harding AE, Thomas PK. Genetic aspects of hereditary motor and sensory neuropathy (type I and II). J Med Genet 1980;17:329-36. 